Prepared in cooperation with the South Bay Salt Pond Restoration Project

\title{
Effects of Human Disturbance on Waterbird Nesting Effort and Reproductive Success at Restoration Pond SF2, South San Francisco Bay, California
}

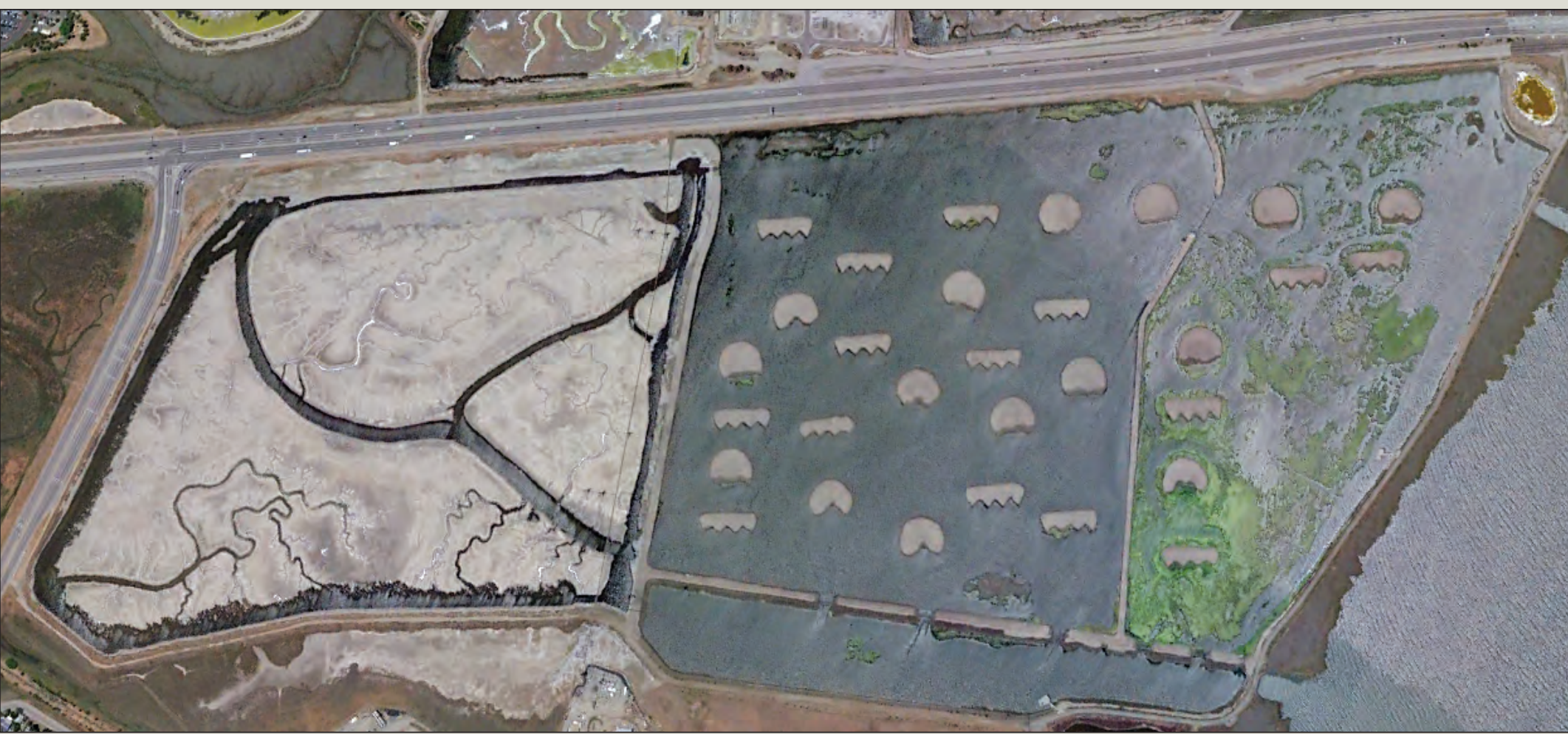

Open-File Report 2014-1223 
Cover: Aerial photograph of Pond SF2 after construction of bird nesting islands. Image from Google Earth®, 2014. 


\section{Effects of Human Disturbance on Waterbird Nesting and Reproductive Success at Restoration Pond SF2, South San Francisco Bay, California}

By Joshua T. Ackerman, Mark P. Herzog, and C. Alex Hartman

Prepared in cooperation with the South Bay Salt Pond Restoration Project

Open-File Report 2014-1223

U.S. Department of the Interior

U.S. Geological Survey 


\section{U.S. Department of the Interior \\ SALLY JEWELL, Secretary}

\section{U.S. Geological Survey \\ Suzette M. Kimball, Acting Director}

U.S. Geological Survey, Reston, Virginia: 2014

For more information on the USGS-the Federal source for science about the Earth,

its natural and living resources, natural hazards, and the environment-visit

http://www.usgs.gov or call 1-888-ASK-USGS (1-888-275-8747)

For an overview of USGS information products, including maps, imagery, and publications, visit http://www.usgs.gov/pubprod

To order this and other USGS information products, visit http://store.usgs.gov

Any use of trade, firm, or product names is for descriptive purposes only and does not imply endorsement by the U.S. Government.

Although this information product, for the most part, is in the public domain, it also may contain copyrighted materials as noted in the text. Permission to reproduce copyrighted items must be secured from the copyright owner.

Suggested citation:

Ackerman, J.T., Herzog, M.P., and Hartman, C.A., 2014, Effects of human disturbance on waterbird nesting and reproductive success at restoration pond SF2, south San Francisco Bay, California: U.S. Geological Survey OpenFile Report 2014-1223, 16 p, http://dx.doi.org/10.3133/ofr20141223.

ISSN 2331-1258(online) 


\section{Contents}

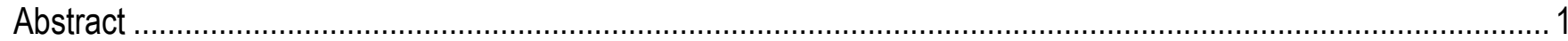

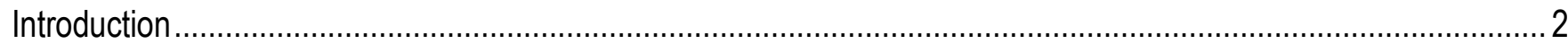

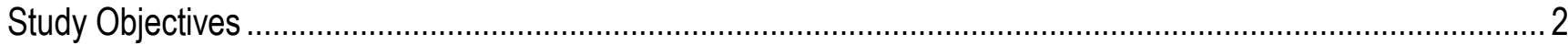

Study Area

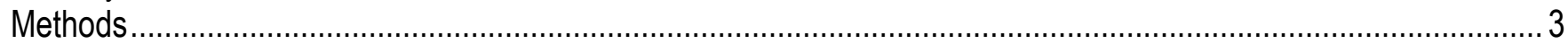

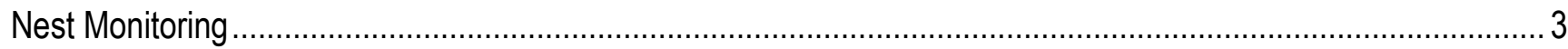

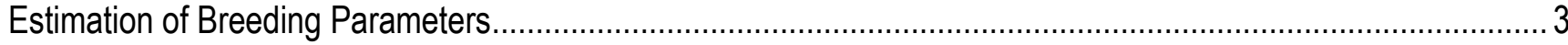

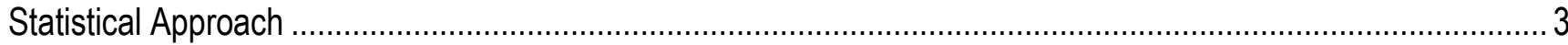

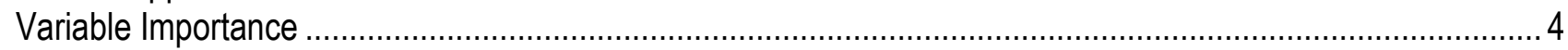

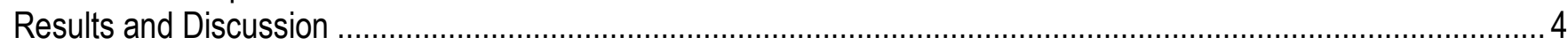

Nesting Performance of Waterbirds at Restoration Pond SF2 in 2011 and 2012 ........................................... 4

Spatial Distribution of Nests Relative to Potential Disturbance Features ........................................................

Disturbance Effects on Breeding Waterbirds.......................................................................................

Nest Success Relative to Distance from Potential Disturbance Features......................................................

Effects of Disturbance Features on Nest Survival ...............................................................................

Effects of Disturbance Features on Nest Initiation Date and Clutch Size ....................................................

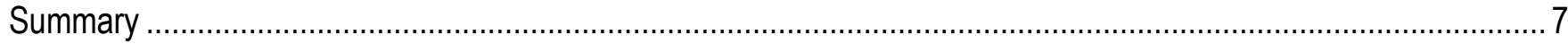

Acknowledgments

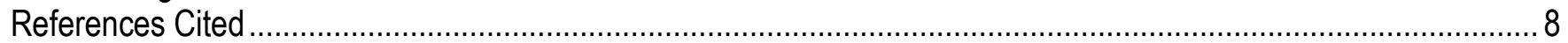

\section{Figures}

Figure 1. Location and final nest fate of American Avocet (Recurvirostra americana) nests at restored Pond SF2, south San Francisco Bay, California, 2011-12 ..................................................................................... 9

Figure 2. American Avocet (Recurvirostra americana) daily nest survival (A) and nest success (B) were lower in nests located farther from the highway (State Route 84), South San Francisco Bay, California.

\section{Tables}

Table 1. Spatial distribution and final nest fate of American Avocet (Recurvirostra americana) nests relative to potential disturbance features at restored Pond SF2, south San Francisco Bay, California, 2011-12.

Table 2. Model selection results for effects of potential disturbance features on daily nest survival of American Avocets (Recurvirostra americana) at restored Pond SF2, south San Francisco Bay, California, 2011-12 ........... 12

Table 3. Relative variable importance metrics for effects of potential disturbance features on daily nest survival of American Avocets (Recurvirostra americana) at restored Pond SF2, south San Francisco Bay, California, 2011-12.

Table 4. Model selection results for effects of potential disturbance features on clutch size of American Avocets (Recurvirostra americana) at restored Pond SF2, south San Francisco Bay, California, 2011-12 ........... 14 Table 5. Relative variable importance metrics for effects of potential disturbance features on clutch size of American Avocets (Recurvirostra americana) at restored Pond SF2, south San Francisco Bay, California, 2011-12.

Table 6. Model selection results for the effects of potential disturbance features on nest initiation date of American Avocets (Recurvirostra americana) at restored Pond SF2, south San Francisco Bay, California, 2011-12.

Table 7. Relative variable importance metrics for effects of potential disturbance features on nest initiation date of American Avocets (Recurvirostra americana) at restored Pond SF2, south San Francisco Bay, California, 2011-12. 


\section{Conversion Factors, and Abbreviations and Acronyms}

\section{Conversion Factors}

\begin{tabular}{|c|c|c|}
\hline Multiply & By & To obtain \\
\hline \multicolumn{3}{|c|}{ Length } \\
\hline foot (ft) & 0.3048 & meter $(\mathrm{m})$ \\
\hline \multicolumn{3}{|l|}{ SI to Inch/Pound } \\
\hline Multiply & By & To obtain \\
\hline \multicolumn{3}{|c|}{ Length } \\
\hline meter $(\mathrm{m})$ & 3.281 & foot (ft) \\
\hline meter $(\mathrm{m})$ & 1.094 & yard (yd) \\
\hline \multicolumn{3}{|c|}{ Area } \\
\hline square meter $\left(\mathrm{m}^{2}\right)$ & 0.0002471 & acre \\
\hline square meter $\left(\mathrm{m}^{2}\right)$ & 10.76 & square foot $\left(\mathrm{ft}^{2}\right)$ \\
\hline hectare (ha) & 2.471 & acre \\
\hline hectare (ha) & 0.003861 & square mile $\left(\mathrm{mi}^{2}\right)$ \\
\hline
\end{tabular}

\section{Abbreviations and Acronyms}

$\begin{array}{ll}\text { AIC } & \text { Akaike's Information Criterion } \\ \mathrm{Cl} & \text { confidence interval } \\ R^{2} & \text { coefficient of determination } \\ \mathrm{SBSP} & \text { South Bay Salt Pond } \\ \mathrm{VI} & \text { variable importance }\end{array}$




\title{
Effects of Human Disturbance on Waterbird Nesting and Reproductive Success at Restoration Pond SF2, South San Francisco Bay, California
}

\author{
By Joshua T. Ackerman, Mark P. Herzog, and C. Alex Hartman
}

\begin{abstract}
To offset for the loss of managed pond habitat during restoration of wetlands to tidal marsh, the South Bay Salt Pond (SBSP) Restoration Project is enhancing some of the remaining ponds by constructing islands for roosting and nesting waterbirds. Among these wetland habitats, the SBSP Restoration Project also is installing walking trails and viewing platforms in an effort to bring the public closer to nature. In winter of 2010-11, the SBSP Restoration Project constructed 30 islands in Pond SF2 and walking trails and viewing platforms around the edge of the pond. The restoration project partners acknowledged that human disturbance could detrimentally affect nesting and roosting waterbirds. Although optimal buffer distances and potential for human disturbance were unknown, islands in Pond SF2, nevertheless, were designed with built-in buffers of greater than 300 feet ( 91 meters) from a trail and 600 feet (182 meters) from a viewing platform in order to minimize potential human disturbances.

To determine the effects that human disturbance may have on waterbirds nesting on these newly constructed islands in Pond SF2, we assessed the potential effects of human disturbance features (specifically, access trails, viewing platforms, internal pond berms, exterior levees, and highways) on breeding waterbirds in 2011 and 2012. We found no clear pattern of potential disturbance features on a group of reproductive factors, including nest survival, nest initiation date, and clutch size. Because all the islands were constructed greater than 90 meters from the nearest disturbance feature, Pond SF2 alone did not provide adequate variation in the distance of disturbance features to detect potential detrimental effects for islands closer to disturbance features in other areas of the SBSP Restoration Project. If there is a need for SBSP Restoration Project Management Team to understand how close islands can be built to disturbance features in the future, we suggest a more comprehensive study that includes multiple ponds, other than SF2, with islands at varying distances to disturbance features.
\end{abstract}




\section{Introduction}

San Francisco Bay is the largest estuary on the West Coast of North America, but nearly all tidal marshes and tidal flats have been destroyed due to urban development, agriculture, and salt production (Goals Project, 1999). In an effort to restore tidal habitat in South San Francisco Bay, the South Bay Salt Pond (SBSP) Restoration Project is implementing a plan to convert 50-90 percent of these former salt ponds into tidal and managed marsh habitats within the next 50 years (Goals Project, 1999; Steere and Schaefer, 2001; Siegel and Bachand, 2002; Life Science!, 2003).

The San Francisco Bay annually supports more than 1 million waterbirds and is a RAMSARdesignated site of hemispheric importance for the conservation of shorebirds (Page and others, 1999; Morrison, 2001; Stenzel and others, 2002). Shorebird abundances during peak spring migration have exceeded 200,000 shorebirds in a single salt pond (Stenzel and Page, 1988). Although the restoration of former salt ponds to tidal marsh will increase habitat for many animals, it also will reduce the overall availability of pond habitats for wintering, migratory, and breeding waterbirds. A goal of the SBSP Restoration Project is to maintain current waterbird populations. Toward this goal, the first phase of the SBSP Restoration Project is to reconfigure and enhance two existing ponds (Ponds A16 and SF2) by constructing islands to increase roosting and foraging opportunities and to provide waterbird nesting habitat (Trulio and others, 2007). The number of waterbirds breeding within Pond SF2 (especially American Avocets [Recurvirostra americana], Black-necked Stilts [Himantopus mexicanus], and Forster's Terns [Sterna forsteri]) are expected to increase with the additional nesting islands, but increased public access and associated human disturbance may potentially detrimentally affect reproductive success. (These birds are referred to hereafter as "Avocets," "Stilts," and "Terns," respectively.) For example, birds may flush and leave nests unprotected from predators in response to public activity occurring in close proximity to nesting sites. In addition to the potential overt effect of disturbance on nest mortality, disturbance also may affect overall reproductive output. Immediate disturbance may cause a pair to abandon their clutch or to lay fewer eggs. Birds avoiding disturbance also may select less-optimal nesting sites that may be more vulnerable to predation. Thus, in addition to the potential effect of disturbance on nest survival, clutch size and placement of nest sites also might be affected by disturbance. At the request of the SBSP Restoration Project Team, we were asked to examine the effect of disturbance features within Pond SF2 on waterbird reproductive success during the 2011 and 2012 breeding seasons. Disturbance features examined included internal berms, and proximities to Highway 84 (State Route 84), a perimeter levee, viewing platforms (placed at least $182 \mathrm{~m}$ from constructed islands), or walking trails (placed at least $91 \mathrm{~m}$ from constructed islands).

\section{Study Objectives}

The goals of this study were:

1. To estimate nesting performance (nest survival, clutch size, and nest initiation date) of nesting waterbird species (Avocets, Stilts, or Terns) within the outer two cells of Pond SF2 that were enhanced with 30 nesting islands.

2. To quantify the effects that the proximity of disturbance features (specifically, access trails, viewing platforms, internal pond berms, exterior levees, and highways) has on reproductive success.

\section{Study Area}

The study area for this supplemental proposal was enhanced Pond SF2, located within the Ravenswood complex of historical salt ponds (fig. 1). 


\section{Methods}

\section{Nest Monitoring}

Throughout the nesting season (April-August 2011 and 2012), all 30 islands in Pond SF2 were visited weekly to monitor waterbird nesting activity. We uniquely marked each newly initiated nest, and recorded Universal Transverse Mercator (UTM) coordinates of each nest (Garmin ${ }^{\circledR}$ GPSMAP 76, Garmin International Inc., Olathe, Kansas). At each weekly nest visit, we floated eggs to determine embryo age (Ackerman and Eagles-Smith, 2010), recorded clutch size, determined overall nest fate (hatched, failed, abandoned, or depredated), and determined the fate of each individual egg (hatched, failed-to-hatch, abandoned, or depredated).

\section{Estimation of Breeding Parameters}

Daily nest survival rates were estimated based on weekly nest visits using logistic exposure models (Shaffer, 2004). A nest was considered to have survived an interval if the clutch was still completely or partially intact, embryo development had progressed, and there were no signs of nest abandonment (such as cold eggs). A nest was considered successful if 1 or more eggs successfully hatched. A nest was considered unsuccessful if it was depredated or abandoned. Exposure days were calculated as the number of days between nest visits, except when a final nest fate occurred between visits (hatched, depredated, or abandoned). For hatched nests, exposure days were calculated for the final interval based on the expected hatch date (Ackerman and Eagles-Smith, 2010). For depredated nests, exposure days were calculated for the final interval as the mid-point between nest visits. For abandoned nests, exposure days for the final interval were calculated as the difference between the developmental age of the eggs when the nest was abandoned (estimated by egg flotation) and the developmental age of the eggs when the nest was last visited. We censored nests that were abandoned because of investigator disturbance (such as egg collections). Nest success was calculated as the model averaged product of daily nest survival over the 27-day egg-laying and incubation period (Ackerman and others, 2013).

Clutch size was estimated as the total number of eggs laid per female in a single nest. To reduce error associated with partial clutch depredation, we limited the estimation of clutch size to only nests we initially detected during laying or within 8 days of the onset of incubation.

Nest initiation date was defined as the date on which the first egg of the nest was laid. For nests detected during egg-laying, we assumed one egg was laid per day and, thus, nest initiation date was estimated as the date the nest was detected minus the number of eggs in the nest when detected. For nests detected after incubation had started, we assumed incubation began when the last egg was laid, and nest initiation date was estimated as the date the nest was detected minus the average age of eggs (in days) and the number of eggs in the nest.

\section{Statistical Approach}

All statistical analyses were done using R 3.1.1 (R Core Team, 2014). All modeling was done using an information-theoretic approach (Burnham and Anderson, 2002). Nest survival models (as described in section, "Estimation of Breeding Parameters") used the logistic exposure method (Shaffer, 2004). Standard linear models were used to examine the effects of disturbance features on clutch size and nest initiation date. Predictions and covariate slope estimates were model-averaged estimates over the full suite of a priori models. 


\section{Variable Importance}

We developed an additional metric, variable importance $(V I)$, in order to provide a more usable measure of the importance of a given variable within a suite of models by comparing the difference in final (or posterior) parameter weight with its initial (or prior) weighting. Prior weighting represents the expected parameter likelihood if all models are equally weighted. This is simply represented as the proportion of models within the full a priori model set in which a given variable is present. The posterior model weighting is defined as the parameter likelihood, or the sum of the model Akaike's Information Criterion $\left(\mathrm{AIC}_{c}\right)$ weights for the set of models when the given variable was present (Burnham and Anderson, 2002). Variable importance was defined as the log-odds ratio of the posterior and prior variable weights, and was described as follows:

$$
\begin{aligned}
& P_{0}=\text { Prior Variable Weight } \\
& \begin{array}{c}
P=\text { Posterior Variable Weight (or parameter likelihood) } \\
\text { Variable Importance }(V I)=\log \left[\frac{\left(\frac{P}{1-P}\right)}{\left.\left(\frac{P_{0}}{1-P_{0}}\right)\right]}\right. \\
=\log \left(\frac{P}{1-P}\right)-\log \left(\frac{P_{0}}{1-P_{0}}\right) \\
=\operatorname{logit}(P)-\operatorname{logit}\left(P_{0}\right)
\end{array}
\end{aligned}
$$

Similar to the standard parameter likelihood, the variable importance metric, $V I$, provides a relative measure of how much a given variable is supported by the data and is calculated by summing all the model weights where the variable was present and comparing this value to the parameter likelihood of the other variables. However, VI also attempts to correct for the potential bias that may exist when the a priori model set is unbalanced and some variables are included in more models than others (that is, when the prior variable weights $\left(\mathrm{P}_{0}\right)$ are not the same for all variables).

\section{Results and Discussion}

\section{Nesting Performance of Waterbirds at Restoration Pond SF2 in 2011 and 2012}

We located a total of 170 Avocet nests (166 nests in 2011; 4 nests in 2012) at Pond SF2 (table 1; fig. 1). Although Stilts nested in small numbers within the salt pan of Pond SF2 (cell 3), Stilt nests were not observed within the regions of the pond that were enhanced with nesting islands. Terns did not nest at Pond SF2 in 2011 or 2012. Hereafter, all nesting statistics are for Avocets.

In 2011, the average nest initiation date for Avocets at Pond SF2 was May 7, and average clutch size was $3.77 \pm 0.06$ eggs. These results are comparable to the long-term records for nest initiation dates and clutch sizes (Ackerman and Herzog, 2012; Ackerman and others, 2013). In 2012, the nest initiation date was similar (May 5); however, clutch size was significantly less $(2.92 \pm 0.18)$, but most likely represents the small sample size of only 4 nests.

The percentage of nests that were successful was 64 percent (109 of 170 nests); all successful nests occurred in 2011, and the 4 nests observed in 2012 failed (table 1). Partial depredation (the loss of 1 or more eggs without the full nest being depredated) occurred on 42 (38.5 percent) of the successful nests. A total of 50 nests (29.4 percent) were destroyed by predators, and 6.5 percent of nests were abandoned. Overall nest success in 2011 for Avocets at Pond SF2 was 57.8 percent (95-percent confidence interval $[\mathrm{CI}]=43.1-69.4$ percent; $N=166$ ), based on a simple logistic exposure model of daily survival, with age of nest as the only covariate and a 27 day incubation period). 


\section{Spatial Distribution of Nests Relative to Potential Disturbance Features}

Given the small sample of nests observed at Pond SF2 in 2012, there was no statistical power to detect differences in spatial distribution between years, and all summary statistics and analyses presented are with all years combined. In 2011 and 2012, Avocets nested an average of $142 \pm 7 \mathrm{~m}$ from berms, $329 \pm 9 \mathrm{~m}$ from the highway, $188 \pm 5 \mathrm{~m}$ from levees, $315 \pm 9 \mathrm{~m}$ from viewing platforms, and 221 $\pm 6 \mathrm{~m}$ from publically accessible trails. For each island, we overlaid a grid with 1-m spacing, and measured the distance of disturbance features to the centroid of each $1-\mathrm{m}^{2}$ pixel using the Spatial Analyst extension 10.2 for ArcMap ${ }^{\mathrm{TM}} 10.2$ (Environmental Research Systems Institute, Inc., Redlands, California). Island polygons were digitized from 2010 high-resolution imagery acquired by the San Francisco Bay Estuary Field Station of the U.S. Geological Survey Western Ecological Research Center. Distance values then were averaged over all pixels to provide average distances to each disturbance feature (table 1). Using individual nest Global Positioning System coordinates, we identified which $1-\mathrm{m}^{2}$ pixels on each island were used or not used for nesting. Based on Welch's twosample t-test, and assuming all locations on all islands were suitable for nesting, Avocets nested $16 \mathrm{~m}$ farther from trails (95-percent $\mathrm{CI}=6-25 ; t=-3.21 ; \mathrm{df}=170.36 ; p=0.002)$, and $33 \mathrm{~m}$ closer to viewing platforms (95-percent $\mathrm{CI}=17-51 ; t=3.94 ; \mathrm{df}=170.15 ; p=0.0001)$ than would be expected by chance. We did not detect any differences among unused locations and actual nest locations for distance to highway $(t=0.40 ; \mathrm{df}=170.28 ; p=0.69)$, distance to trail $(t=1.607 ; \mathrm{df}=170.38 ; p=0.11)$, or distance to internal berms $(t=-1.34 ; \mathrm{df}=170.15 ; p=0.18)$.

\section{Disturbance Effects on Breeding Waterbirds}

\section{Nest Success Relative to Distance from Potential Disturbance Features}

There were no differences in the location of successful nests and unsuccessful nests with respect to their distance from highways $(t=1.64 ; \mathrm{df}=111.61 ; p=0.10)$, internal berms $(t=0.08 ; \mathrm{df}=110.41$; $p=0.94)$, levees $(t=-0.43 ; \mathrm{df}=132.75 ; p=0.67)$, viewing platforms $(t=1.39 ; \mathrm{df}=117.44 ; p=0.17)$, or trails $(t=1.22 ; \mathrm{df}=114.88 ; p=0.23)$.

\section{Effects of Disturbance Features on Nest Survival}

We required nest age to be in all models, and daily nest survival was negatively related to nest initiation date (tables 2 and 3). Variable importance $(V I)$ was extremely high (17.76) for nest initiation date, indicating strong support for inclusion of this variable. In fact, cumulative model weight for models that included both nest age and initiation date exceeded 0.99, which suggests that a model with these two variables is $1.5 \times 10^{7}$ times more likely to represent the processes within the observed data than any of the a priori models that did not include them. Although a model that included a quadratic relationship with nest age performed nearly as well as the model with a linear relationship $\left(\Delta \mathrm{AIC}_{\mathrm{c}}=0.24\right)$, variable importance for the quadratic term was negative, indicating that this variable was not supported. We, therefore, interpreted the potential effects of disturbance features in relation to a base model of nest age and nest initiation date because these variables were so important for estimating Avocet nest survival. 
In accordance with the general patterns observed in nest success of Avocets at Pond SF2 (table 1), the models of daily nest survival provide some support for an increase in daily nest survival for Avocets that nest closer to the highway (table 2). Additionally, $V I$ was 1.94, indicating that these data support the inclusion of this variable in models of daily survival rate. However, the 95-percent CI of the model-averaged covariate $(\beta=-0.003-0.001)$ associated with the distance of nest from highway includes zero, which indicates there also is uncertainty regarding the magnitude of this effect. Model-averaged estimates of daily survival rate decreased linearly over the observed range of distances that nests were found from the highway, indicating that daily survival rate was lower for nests observed farther from the highway (fig. 2A). Avocet nests are typically incubated for 27 days (Ackerman and others, 2013), resulting in model-average nest success estimates that vary from 56.7 percent for nests farthest away from the highway ( $566 \mathrm{~m}$; 95-percent $\mathrm{CI}=23.3-79.3$ percent) to 73.1 percent for those nests closest to the highway ( $138 \mathrm{~m}$; 95-percent $\mathrm{CI}=46.5-87.5$ percent; fig. $2 B)$.

All other disturbance variables included in the a priori candidate model set were not supported by these data (tables 2 and 3). Variable importance for all other variables was negative (indicating a lack of support; table 3) and model weight was at most 0.04 (and usually much lower), indicating that the top model was at least 6.99 times more likely than any other model that included distance from a potential disturbance feature (table 2).

\section{Effects of Disturbance Features on Nest Initiation Date and Clutch Size}

Clutch size decreased in later initiated nests ( $\beta_{\text {initdate }}=-0.011 \pm 0.003$; tables 4 and 5$)$. The only disturbance feature that may have influenced clutch size in these data was the distance to levee, but the data only provide weak support for this hypothesis. Avocets that nested farther from the Pond SF2 levees appeared to have higher clutch sizes, because the model with distance to the nearest levee was 1.89 times more likely than the same model without it included (table 4$)$. The top model explained only 13 percent of the total variation $\left(R^{2}=0.13\right)$ and the model-average slope for the distance to levee covariate showed substantial variation, with 95-percent CI including the possibility of no effect (95percent CI for $\beta_{\text {levee }}=-0.0001-0.004$; table 5). Although these data support the hypothesis that the clutch size of Avocet nests increases for nests farther from the levee, it is difficult to infer that activities of disturbance on the levee are the cause for this decrease. Instead, this relationship may indicate that highquality sites are farther from the levee and are selected earlier by high-quality pairs, and high-quality pairs have, on average, a larger clutch. Regardless of the potential cause, the overall effect on clutch size was relatively minor and overlapped the possibility of no effect.

Initiation date of Avocet nests increased with the distance the nest was located from a viewing platform (table 6). In fact, this relationship was by far the most supported hypothesis among the $a$ priori candidate model set and was 121 times more likely than any other model. Model-averaged estimates suggest that initiation date increased as much as 6 days for every $100 \mathrm{~m}$ farther from a viewing platform the nest was located $\left(\beta_{\text {platform }}=0.060 \pm 0.017\right.$; table 7$)$. However, overall model performance was poor $\left(R^{2}=0.06\right)$ and distance from disturbance features explained little of the overall variation observed in Avocet nest initiation date. Similar to our conclusion with clutch size, we believe this pattern of increasing nest initiation date farther from viewing platforms may indicate settling patterns unrelated to the actual disturbance features. Regardless, given that nests closer to the viewing platform are initiated earlier, there does not appear to be any detrimental effects caused directly by human disturbance associated with the viewing platform at the distances observed. 


\section{Summary}

Although various factors generally influence specific reproductive or nesting characteristics, there was no consistent pattern that showed any linkages between negative breeding performance and potential disturbance features. Instead, several positive relationships with potential disturbance features were documented, including earlier nesting dates the closer the nest was located to a viewing platform, larger clutch sizes for nests located closer to a pond levee, and increased nest success the closer the nest was located to the highway. Whether these relationships reflect causal relationships is unknown, but there were no observable detrimental effects on waterbird reproductive performance caused by these potential disturbance features.

However, most of the public viewing features had minimal visitation by humans, and, therefore minimal disturbance levels during the 2011 and 2012 breeding seasons, relative to other ponds that received higher use by the public. Pond SF2 also lacked the necessary islands close enough in proximity to potential disturbance features to detect effects of human disturbance on nesting waterbirds. Specifically, all islands in Pond SF2 were located more than 90 meters from public access trails and more than 180 meters from public viewing platforms. Therefore, we were not able to estimate the expected effects of public-access features on the reproductive success of waterbirds across the range of distances that already occur throughout the SBSP Restoration Project area. If the ultimate goal is to understand the buffer distance necessary to avoid disturbance effects on breeding waterbirds, then a larger study (involving multiple ponds with islands at varying distances to potential disturbance features) is necessary. A management tool could be generated from such a study to estimate the appropriate buffer distance for placement of future constructed islands, and the placement of walking trails and viewing platforms at ponds that already have existing nesting island habitat.

Given these data limited to only Pond SF2, we would not expect detrimental effects on birds nesting on islands located more than 90 meters away from potential disturbance features. However, we cannot provide any assessment about how much closer to disturbance features islands could be built and still not influence breeding performance without a larger study including more ponds and more islands at varying distances from potential disturbance features.

\section{Acknowledgments}

This study was funded by the Resources Legacy Fund and South Bay Salt Pond Restoration Project. Logistical support was kindly provided by Cheryl Strong, Eric Mruz, Laura Valoppi, John Bourgeois, and John Krause, and the staffs of the Don Edwards San Francisco Bay National Wildlife Refuge and Eden Landing Ecological Reserve. We thank the following U.S. Geological Survey, Dixon Field Station staff who helped with this research: Tabitha McKinney, Trevor Watts, Jessica LaCoss, Nina Hill, Jarred Barr, Kristen Boysen, Sarah Flaherty, Nicolette Roach, and Camille Yabut. 


\section{References Cited}

Ackerman, J.T., and Eagles-Smith, C.A., 2010, Accuracy of egg flotation throughout incubation to determine embryo age and incubation day in waterbird nests: Condor, v. 112, no. 3, p. 438-446.

Ackerman, J.T., Hartman, C.A., Herzog, M.P., Takekawa, J.Y., Robinson, J.A., Oring, L.W., Skorupa, J.P., and Boettcher, R., 2013, American Avocet (Recurvirostra americana), in Poole, A., ed., The Birds of North America Online: Ithaca, New York, Cornell Lab of Ornithology.

Ackerman, J.T., and Herzog, M.P., 2012, Waterbird nest monitoring program in San Francisco Bay (2005-2010): U.S. Geological Survey Open-File Report 2012-1145, p. 16.

Burnham, K.P., and Anderson, D.R., 2002, Model selection and multimodel inference-A practical information-theoretic approach (2d ed.): New York. Springer-Verlag, 488 p.

Goals Project, 1999, Baylands ecosystem habitat goals-A report of habitat recommendations prepared by the San Francisco Bay Area Wetlands Ecosystem Goals Project: U.S. Environmental Protection Agency, San Francisco, California and San Francisco Bay Regional Water Quality Control, Board, Oakland, California, $328 \mathrm{p}$.

Life Science!, 2003, South Bay Salt Ponds Initial Stewardship Plan: Woodland, California, 212 p.

Morrison, R.I.G., 2001, Trends in shorebird populations in North America using Breeding Bird Survey data: Bird Trends, v. 8, p. 12-15.

Page, G., Stenzel, L., and Kjelmyr, J., 1999, Overview of shorebird abundance and distribution in wetlands of the Pacific Coast of the contiguous United States: Condor, v. 101, no. 3, p. 461-471.

R Core Team, 2014, R-A language and environment for statistical computing: Vienna, Austria, R Foundation for Statistical Computing, ISBN 3-900051-07-0, http:/www.R-project.org/.

Shaffer, T.L., 2004, A unified approach to analyzing nest success: Auk, v. 121, no. 2, p. 526-540.

Siegel, S.W., and Bachand, P.A.M., 2002, Feasibility analysis of South Bay Salt Pond Restoration, San Francisco Estuary, California: Wetlands and Water Resources, San Rafael, California, 228 p.

Steere, J.T., and Schaefer, N., 2001, Restoring the estuary-Implementation strategy of the San Francisco Bay Joint Venture: Oakland, California, San Francisco Bay Joint Venture, 124 p.

Stenzel, L.E., Hickey, C.M., Kjelmyr, J.E., and Page, G.W., 2002, Abundance and distribution of shorebirds in the San Francisco Bay area: Western Birds, v. 33, no. 2, p. 69-98.

Stenzel, L., and Page, G., 1988, Results of the first comprehensive shorebird census of San Francisco and San Pablo Bays: Wader Study Group Bulletin, v. 54, p. 43-48.

Trulio, L.A., Clark, D., Ritchie, S., Hutzel, A., and Team, S., 2007, South Bay Salt Pond Restoration Project_Public Draft Adaptive Management Plan: South Bay Salt Pond Restoration Project, 163 p. 


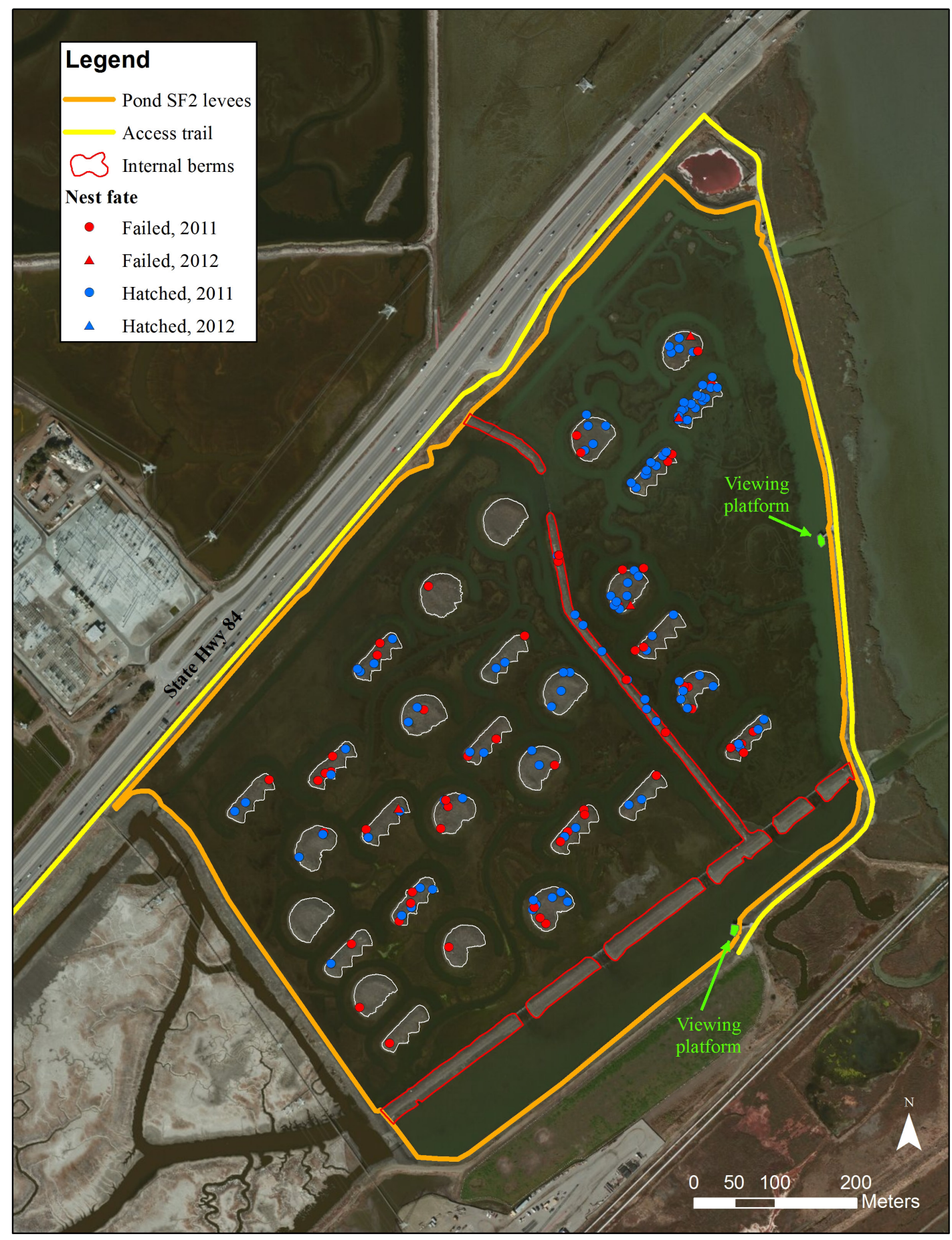

Figure 1. Location and final nest fate of American Avocet (Recurvirostra americana) nests at restored Pond SF2, south San Francisco Bay, California, 2011-12. The 30 newly constructed islands are outlined in white. 
A)

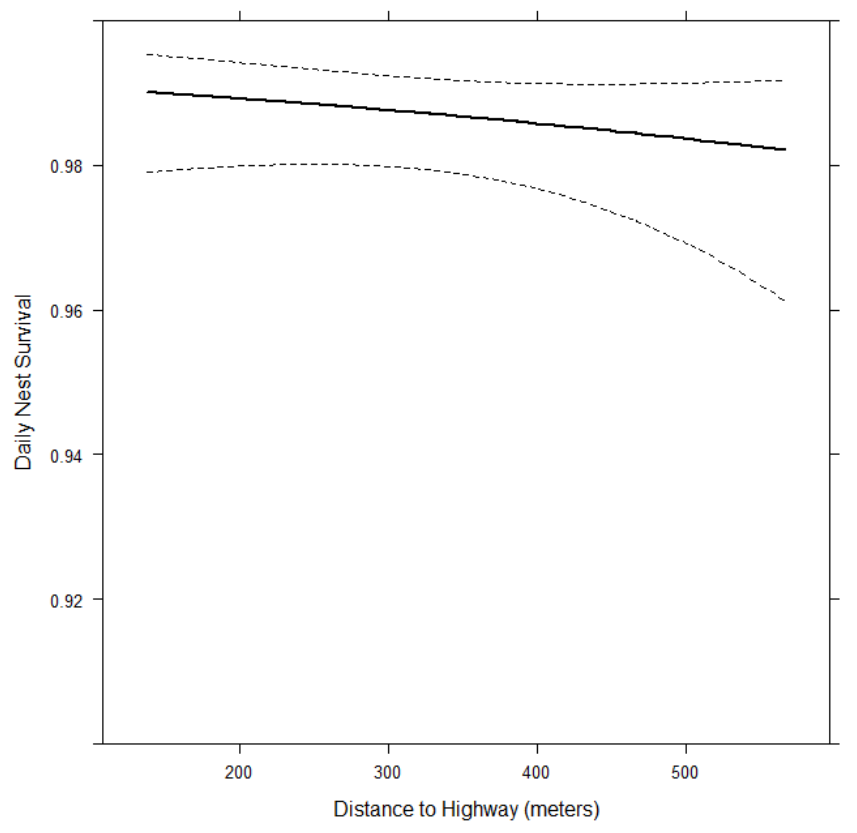

B)

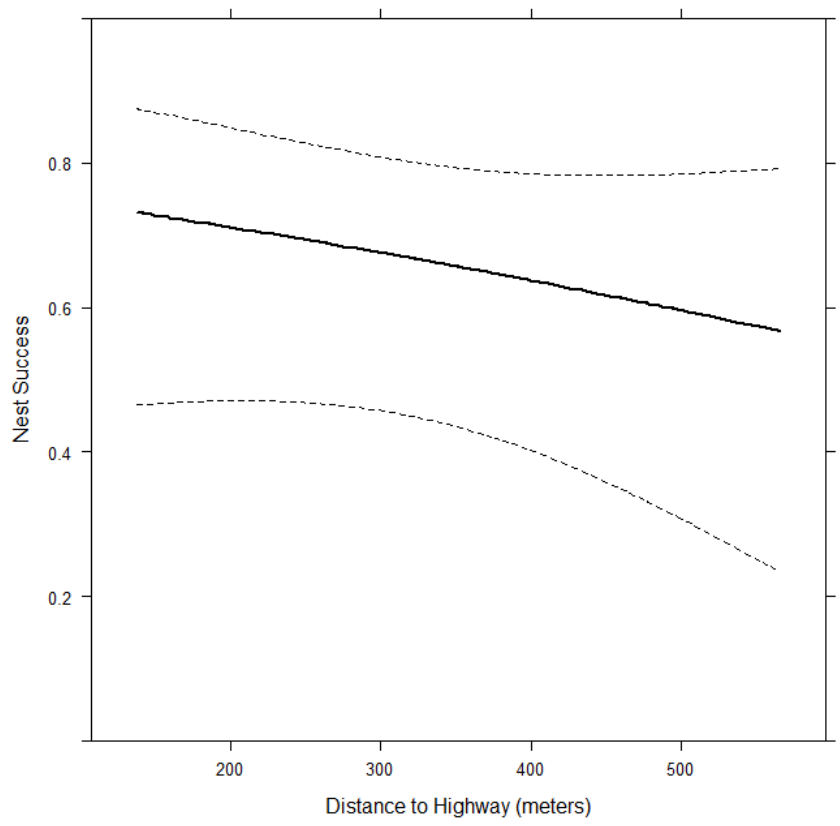

Figure 2. American Avocet (Recurvirostra americana) daily nest survival (A) and nest success (B) were lower in nests located farther from the highway (State Route 84), South San Francisco Bay, California. Solid line represents predicted values, and dashed lines are upper and lower $95 \%$ confidence intervals. 
Table 1. Spatial distribution and final nest fate of American Avocet (Recurvirostra americana) nests relative to potential disturbance features at restored Pond SF2, south San Francisco Bay, California, 2011-12.

[Mean and standard errors are provided for all statistics. Number of nests used to estimate clutch size was a subset of nests found early in incubation (to reduce errors associated with partial clutch depredation) and are provided within parentheses. The final row provides average distances to possible disturbance features for all available nesting habitats within SF2]

\begin{tabular}{|c|c|c|c|c|c|c|c|c|c|}
\hline \multirow{2}{*}{$\begin{array}{l}\text { Final nest } \\
\text { status }\end{array}$} & \multirow{2}{*}{ Year } & \multirow{2}{*}{$\begin{array}{l}\text { Number of } \\
\text { nests }\end{array}$} & \multirow{2}{*}{$\begin{array}{c}\text { Nest } \\
\text { initiation date }\end{array}$} & \multirow{2}{*}{ Clutch size } & \multicolumn{5}{|c|}{$\begin{array}{l}\text { Distance to } \\
\text { (in meters): }\end{array}$} \\
\hline & & & & & Berm & $\begin{array}{l}\text { Highway (State } \\
\text { Route 84) }\end{array}$ & Levee & Platform & Trail \\
\hline \multirow[t]{3}{*}{ Successful } & 2011 & $109(90)$ & April $29 \pm 2$ days & $3.77 \pm 0.06$ & $142 \pm 8$ & $317 \pm 11$ & $190 \pm 6$ & $306 \pm 10$ & $216 \pm 7$ \\
\hline & 2012 & $0(0)$ & - & - & - & - & - & - & - \\
\hline & Average & $109(90)$ & April $29 \pm 2$ days & $3.77 \pm 0.06$ & $142 \pm 8$ & $317 \pm 11$ & $190 \pm 6$ & $306 \pm 10$ & $216 \pm 7$ \\
\hline \multirow[t]{3}{*}{ Unsuccessful } & 2011 & $57(37)$ & May $23 \pm 3$ days & $2.92 \pm 0.18$ & $140 \pm 14$ & $355 \pm 17$ & $185 \pm 8$ & $334 \pm 16$ & $232 \pm 11$ \\
\hline & 2012 & $4(0)$ & May $5 \pm 12$ days & - & $189 \pm 56$ & $270 \pm 35$ & $191 \pm 37$ & $298 \pm 55$ & $207 \pm 41$ \\
\hline & Average & $61(37)$ & May $22 \pm 3$ days & $2.92 \pm 0.18$ & $143 \pm 14$ & $349 \pm 16$ & $185 \pm 8$ & $331 \pm 15$ & $231 \pm 10$ \\
\hline ALL & 2011 & $166(127)$ & May $7 \pm 2$ days & $3.52 \pm 0.08$ & $141 \pm 8$ & $330 \pm 9$ & $188 \pm 5$ & $316 \pm 9$ & $222 \pm 6$ \\
\hline ALL & 2012 & $4(0)$ & May $5 \pm 12$ days & - & $189 \pm 56$ & $270 \pm 35$ & $191 \pm 37$ & $298 \pm 55$ & $207 \pm 41$ \\
\hline$A L L$ & Average & $170(127)$ & May $7 \pm 2$ days & $3.52 \pm 0.08$ & $142 \pm 7$ & $329 \pm 9$ & $188 \pm 5$ & $315 \pm 9$ & $221 \pm 6$ \\
\hline \multicolumn{5}{|c|}{ All Available Habitat } & $132 \pm 0.4$ & $333 \pm 0.6$ & $172 \pm 0.3$ & $349 \pm 0.5$ & $230 \pm 0.4$ \\
\hline
\end{tabular}


Table 2. Model selection results for effects of potential disturbance features on daily nest survival of American Avocets (Recurvirostra americana) at restored Pond SF2, south San Francisco Bay, California, 2011-12.

[Model structure: The + denotes an additive effect. $k$ : The number of parameters in the model, including the intercept and variance. AICc: Akaike's Information Criterion (AICc). $\triangle \mathrm{AIC} c$ : The difference in the value between $\mathrm{AIC} c$ of the current model and the value for the most parsimonious model. Akaike weight $\left(w_{i}\right)$ :The likelihood of the model given the data, relative to other models in the candidate set (model weights sum to 1.0). Cumulative model weight: The cumulative weight of evidence for the top models (model weights sum to 1.0). Evidence ratio: The weight of evidence that the top model is better than the top model, given the candidate model set. Only models with model weight greater than 0.001 and base model (NestAge only) are shown]

\begin{tabular}{|c|c|c|c|c|c|c|c|}
\hline Model structure & $k$ & -2 (LogLikelihood) & $\mathrm{AICC}$ & $\triangle \mathrm{AICC}$ & Model weight & $\begin{array}{c}\text { Cumulative } \\
\text { model } \\
\text { weight }\end{array}$ & Evidence ratio \\
\hline NestAge + InitiationDate + DistanceToHighway & 5 & 351.648 & 361.674 & 0.000 & 0.308 & 0.308 & 1.000 \\
\hline NestAge + NestAge $^{2}+$ InitiationDate + DistanceToHighway & 6 & 349.872 & 361.908 & 0.235 & 0.274 & 0.582 & 1.124 \\
\hline NestAge + InitiationDate & 4 & 356.203 & 364.220 & 2.546 & 0.086 & 0.668 & 3.572 \\
\hline NestAge + NestAge $^{2}+$ InitiationDate & 5 & 354.743 & 364.769 & 3.095 & 0.066 & 0.733 & 4.700 \\
\hline NestAge + InitiationDate + DistanceToTrail & 5 & 355.535 & 365.561 & 3.887 & 0.044 & 0.778 & 6.985 \\
\hline NestAge + InitiationDate + DistanceToBerm & 5 & 355.758 & 365.783 & 4.110 & 0.039 & 0.817 & 7.805 \\
\hline NestAge + NestAge $^{2}+$ InitiationDate + DistanceToTrail & 6 & 353.943 & 365.979 & 4.305 & 0.036 & 0.853 & 8.606 \\
\hline NestAge + NestAge $^{2}+$ InitiationDate + DistanceToBerm & 6 & 354.047 & 366.083 & 4.410 & 0.034 & 0.887 & 9.069 \\
\hline NestAge + InitiationDate + DistanceToPlatform & 5 & 356.136 & 366.162 & 4.488 & 0.033 & 0.919 & 9.432 \\
\hline NestAge + InitiationDate + DistanceToLevee & 5 & 356.189 & 366.215 & 4.541 & 0.032 & 0.951 & 9.684 \\
\hline NestAge + NestAge $^{2}+$ InitiationDate + DistanceToPlatform & 6 & 354.668 & 366.704 & 5.031 & 0.025 & 0.976 & 12.371 \\
\hline NestAge + NestAge ${ }^{2}+$ InitiationDate + DistanceToLevee & 6 & 354.742 & 366.778 & 5.105 & 0.024 & 1.000 & 12.837 \\
\hline NestAge & 3 & 394.596 & 400.607 & 38.933 & 0.000 & 1.000 & $2.85 E+08$ \\
\hline
\end{tabular}


Table 3. Relative variable importance metrics for effects of potential disturbance features on daily nest survival of American Avocets (Recurvirostra americana) at restored Pond SF2, south San Francisco Bay, California, 2011-12.

[Rows in bold indicate variables with some support as important variables influencing nest survival. SE, standard error]

\begin{tabular}{lccccc}
\hline \multicolumn{1}{c}{ Variable } & $\begin{array}{c}\text { Prior variable } \\
\text { weight } \\
\left(\boldsymbol{P}_{0}\right)\end{array}$ & $\begin{array}{c}\text { Parameter } \\
\text { likelihood } \\
(\boldsymbol{P})\end{array}$ & $\begin{array}{c}\text { Variable } \\
\text { importance }\end{array}$ & $\begin{array}{c}\text { Model average } \\
\text { coefficient }\end{array}$ & $\begin{array}{c}\text { SE model- } \\
\text { averaged } \\
\text { coefficient }\end{array}$ \\
\hline NestAge & $\mathbf{1 . 0 0 0}$ & $\mathbf{1 . 0 0 0}$ & - & $\mathbf{0 . 0 8 3}$ & $\mathbf{0 . 0 6 6}$ \\
DayofYear & $\mathbf{0 . 5 0 0}$ & $\mathbf{1 . 0 0 0}$ & $\mathbf{1 7 . 7 6 2}$ & $\mathbf{- 0 . 0 3 9}$ & $\mathbf{0 . 0 0 7}$ \\
DistanceToHighway & $\mathbf{0 . 1 6 7}$ & $\mathbf{0 . 5 8 2}$ & $\mathbf{1 . 9 3 9}$ & $\mathbf{- 0 . 0 0 2}$ & $\mathbf{0 . 0 0 1}$ \\
NestAge $^{2}$ & 0.500 & 0.458 & -0.169 & -0.004 & 0.003 \\
DistanceToTrail $_{\text {DistanceToBerm }}$ & 0.167 & 0.080 & -0.835 & -0.001 & 0.002 \\
DistanceToPlatform & 0.167 & 0.073 & -0.926 & 0.001 & 0.001 \\
DistanceToLevee & 0.167 & 0.058 & -1.187 & 0.000 & 0.001 \\
\hline
\end{tabular}


Table 4. Model selection results for effects of potential disturbance features on clutch size of American Avocets (Recurvirostra americana) at restored Pond SF2, south San Francisco Bay, California, 2011-12.

[Model structure: The + denotes an additive effect. $\boldsymbol{k}$ : The number of parameters in the model, including the intercept and variance. AICc: Akaike's Information Criterion (AIC c). $\triangle \mathrm{AIC} c$ : The difference in the value between AIC $c$ of the current model and the value for the most parsimonious model. Akaike weight $\left(\boldsymbol{w}_{\boldsymbol{i}}\right)$ : The likelihood of the model given the data, relative to other models in the candidate set (model weights sum to 1.0). Cumulative model weight: The cumulative weight of evidence for the top models (model weights sum to 1.0). Evidence ratio: The weight of evidence that the top model is better than the top model, given the candidate model set. Only models with model weight greater than 0.001 and base model (NestAge only) are shown]

\begin{tabular}{|c|c|c|c|c|c|c|c|}
\hline Model & $k$ & -2 (LogLikelihood) & $\mathrm{AlC}_{c}$ & $\Delta \mathrm{AIC}_{c}$ & $\begin{array}{l}\text { Model } \\
\text { weight }\end{array}$ & $\begin{array}{c}\text { Cumulative } \\
\text { model } \\
\text { weight }\end{array}$ & $\begin{array}{c}\text { Evidence } \\
\text { ratio }\end{array}$ \\
\hline InitationDate + DistanceToLevee & 4 & 299.104 & 307.432 & 0.000 & 0.392 & 0.392 & 1.000 \\
\hline InitationDate & 3 & 302.513 & 308.708 & 1.276 & 0.207 & 0.599 & 1.893 \\
\hline InitationDate + DistanceToHighway & 4 & 300.767 & 309.095 & 1.663 & 0.171 & 0.770 & 2.297 \\
\hline nitationDate + DistanceToPlatform & 4 & 302.509 & 310.837 & 3.405 & 0.071 & 0.999 & 5.489 \\
\hline DistanceToLevee & 3 & 315.165 & 321.360 & 13.928 & 0.000 & 0.999 & $1,058.097$ \\
\hline DistanceToHighway & 3 & 315.195 & 321.390 & 13.958 & 0.000 & 1.000 & $1,073.797$ \\
\hline Intercept Only & 2 & 319.052 & 323.149 & 15.717 & 0.000 & 1.000 & $2,587.730$ \\
\hline
\end{tabular}


Table 5. Relative variable importance metrics for effects of potential disturbance features on clutch size of American Avocets (Recurvirostra americana) at restored Pond SF2, south San Francisco Bay, California, 2011-12.

[Rows in bold indicate variables with some support as important variables. SE, standard error]

\begin{tabular}{lccccc}
\hline \multicolumn{1}{c}{ Variable } & $\begin{array}{c}\text { Prior variable } \\
\text { weight } \\
\left(\boldsymbol{P}_{0}\right.\end{array}$ & $\begin{array}{c}\text { Parameter } \\
\text { likelihood } \\
(\boldsymbol{P})\end{array}$ & $\begin{array}{c}\text { Variable } \\
\text { importance }\end{array}$ & $\begin{array}{c}\text { Model average } \\
\text { coefficient }\end{array}$ & $\begin{array}{c}\text { SE model- } \\
\text { averaged } \\
\text { coefficient }\end{array}$ \\
\hline InitiationDate & $\mathbf{0 . 5 0 0}$ & $\mathbf{0 . 9 9 9}$ & $\mathbf{6 . 8 0 4}$ & $\mathbf{- 0 . 0 1 1}$ & $\mathbf{0 . 0 0 3}$ \\
DistanceToLevee & $\mathbf{0 . 1 6 7}$ & $\mathbf{0 . 3 9 2}$ & $\mathbf{1 . 1 7 2}$ & $\mathbf{0 . 0 0 2}$ & $\mathbf{0 . 0 0 1}$ \\
DIstanceToHighway & $\mathbf{0 . 1 6 7}$ & $\mathbf{0 . 1 7 1}$ & $\mathbf{0 . 0 3 1}$ & $\mathbf{- 0 . 0 0 1}$ & $\mathbf{0 . 0 0 1}$ \\
DistanceToBerm & 0.167 & 0.084 & -0.783 & $-4.48 \mathrm{E}-04$ & 0.001 \\
DistanceToTrail & 0.167 & 0.074 & -0.916 & $-2.52 \mathrm{E}-04$ & 0.001 \\
DistanceToPlatform & 0.167 & 0.072 & -0.954 & $3.96 \mathrm{E}-05$ & 0.001 \\
\hline
\end{tabular}

Table 6. Model selection results for the effects of potential disturbance features on nest initiation date of American Avocets (Recurvirostra americana) at restored Pond SF2, south San Francisco Bay, California, 2011-12.

[Model structure: The + denotes an additive effect. $\boldsymbol{k}$ : The number of parameters in the model, including the intercept and variance. AICc: Akaike's Information Criterion (AICc). $\triangle \mathrm{AIC} c$ : The difference in the value between AIC $c$ of the current model and the value for the most parsimonious model. Akaike weight $\left(\boldsymbol{w}_{\boldsymbol{i}}\right)$ : The likelihood of the model given the data, relative to other models in the candidate set (model weights sum to 1.0). Cumulative model weight: The cumulative weight of evidence for the top models (model weights sum to 1.0). Evidence ratio: The weight of evidence that the top model is better than the top model, given the candidate model set. Only models with model weight greater than 0.001 and base model (NestAge only) are shown]

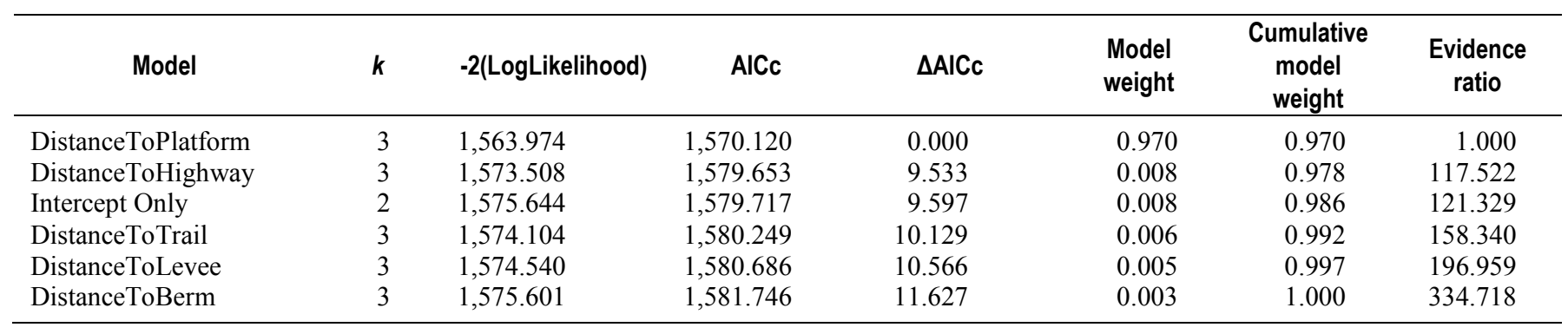


Table 7. Relative variable importance metrics for effects of potential disturbance features on nest initiation date of American Avocets (Recurvirostra americana) at restored Pond SF2, south San Francisco Bay, California, 2011-12.

[Rows in bold indicate variables with some support as important variables. SE, standard error]

\begin{tabular}{lccccc}
\hline \multicolumn{1}{c}{ Variable } & $\begin{array}{c}\text { Prior variable } \\
\text { weight } \\
\left(\boldsymbol{P}_{\mathbf{0}}\right)\end{array}$ & $\begin{array}{c}\text { Parameter } \\
\text { likelihood } \\
(\boldsymbol{P})\end{array}$ & $\begin{array}{c}\text { Variable } \\
\text { importance }\end{array}$ & $\begin{array}{c}\text { Model average } \\
\text { coefficient }\end{array}$ & $\begin{array}{c}\text { SE model- } \\
\text { averaged } \\
\text { coefficient }\end{array}$ \\
\hline DistanceToPlatform & $\mathbf{0 . 1 6 7}$ & $\mathbf{0 . 9 7 0}$ & $\mathbf{5 . 0 7 9}$ & $\mathbf{0 . 0 6 0}$ & $\mathbf{0 . 0 1 7}$ \\
DistanceToHighway & 0.167 & 0.008 & -3.180 & 0.024 & 0.017 \\
DistanceToTrail & 0.167 & 0.006 & -3.480 & 0.033 & 0.026 \\
DistanceToLevee & 0.167 & 0.005 & -3.699 & -0.032 & 0.031 \\
DistanceToBerm & 0.167 & 0.003 & -4.232 & 0.004 & 0.021 \\
\hline
\end{tabular}


Publishing support provided by the U.S. Geological Survey

Publishing Network, Tacoma Publishing Service Center

For more information concerning the research in this report, contact the Director, Western Ecological Research Center

U.S. Geological Survey

3020 State University Drive East

Sacramento, California 95819

http://werc.usgs.gov/ 
